\title{
cAMP acts in synergy with E1A protein to activate transcription of the adenovirus early genes $\mathrm{E} 4$ and E1A
}

\author{
Daniel A. Engel, Stephen Hardy, and Thomas Shenk ${ }^{1}$ \\ Department of Biology, Princeton University, Princeton, New Jersey 08544 USA
}

\begin{abstract}
The transcriptional control regions of several E1A-inducible adenovirus early genes contain sequences similar to the cAMP response element of several cellular cAMP-inducible genes. The cAMP-responsive cell line S49 was infected with wild-type adenovirus and found to contain elevated levels of mRNAs encoded by all early genes tested (E4, E1A, and E1B), following treatment with dibutyryl cAMP. This effect was at the level of transcriptional activation. The effect of CAMP on E4 and E1A transcription was greater in cells infected with wild-type virus than in cells infected with virus that lacked functional E1A proteins. cAMP in combination with E1A generated a greater induction than the product of the increases achieved by each inducer alone. Therefore, cAMP acted in synergy with E1A to induce maximally transcription of the E4 and E1A genes. These data suggest that E1A or E1A-stimulated events can interact functionally with targets of cAMP signaling in the cell to induce transcription of the adenovirus early genes.
\end{abstract}

[Key Words: Adenovirus; transcription; E1A; cAMP; cAMP-dependent protein kinase]

Received August 5, 1988; revised version accepted September 29, 1988.

The E1A proteins of adenovirus are able to regulate transcription of a number of viral and cellular genes (for review, see Berk 1986). This regulation takes the form of activation (Berk et al. 1979; Jones and Shenk 1979a; Nevins 1981) or repression (Borrelli et al. 1984; Hen et al. 1985; Velcich and Ziff 1985; Stein and Ziff 1987), depending on the target gene. During adenovirus infection, the ElA gene is the first viral gene to be transcribed (Nevins et al. 1979). At early times postinfection, E1A protein acts to stimulate transcription of the other adenovirus early genes, termed E1B, E2, E3, and E4, as well as the E1A gene itself (for review, see Berk 1986).

The early viral genes have been the most extensively studied targets of E1A transcriptional activation. The mechanism by which E1A stimulates transcription of these genes is not known. Their coordinate regulation implies that some common molecular events are involved, but analysis of the promoters of these genes has not led to a simple hypothesis pertaining to all of them. Evidence is growing that transcriptional control of the early genes is complex (for review, see Jones et al. 1988), and there may be several mechanisms by which E1A can activate transcription.

Conceivably, E1A could influence transcription by binding directly to DNA. E1A has been shown to associate nonspecifically with DNA in some assays (Ko et al. 1986; Chatteriee et al. 1988) but not in others (Ferguson

${ }^{1}$ Corresponding author. et al. 1985). Alternatively, E1A may serve to activate or modify cellular transcription factors that recognize specific sequences within the early gene promoters, possibly by interacting with these factors directly. E1A could also act by increasing the level of such factors in the cell (for review, see Berk 1986). In the case of the adenovirus VAI gene, there is evidence for an increase in the activity and/or level of transcription of TFIIIC, which stimulates RNA polymerase III transcription of VAI RNA in response to E1A protein (Hoeffler and Roeder 1985; Yoshinaga et al. 1986; Hoeffler et al. 1988). Also, the binding of a factor termed E2F to DNA upstream of the E2 and E1A mRNA start sites is enhanced dramatically during adenovirus infection (Kovesdi et al. 1986a,b; S. Hardy and T. Shenk, in prep.).

cAMP response element binding protein (CREB) binds to a sequence termed the CAMP response element, or CRE (Montminy and Bilezikjian 1987). Sequences that are very similar or identical to the core CRE sequence TGACGTCA are found in the promoters of the cAMPinducible genes somatostatin (Montminy et al. 1986), tyrosine hydroxylase (Lewis et al. 1987), c-fos (Greenberg et al. 1985), phosphoenolpyruvate carboxykinase (PEPCK) (Short et al. 1986), and the $\alpha$-subunit of human chorionic gonadotropin ( $\alpha$-hCG) (Silver et al. 1987). Deletion mutagenesis of the somatostatin, PEPCK, and $\alpha$-hCG genes has shown that domains necessary for cAMP-mediated induction of transcription contain a CRE, or CRE-like sequence (Montminy et al. 1986; Short et al. 1986; Silver et al. 1987). CRE-like sequences 
are also located in the promoters of the E1A, E2A, E3, and $\mathrm{E} 4$ genes, and these sites have been shown to bind CREB in vitro (Hardy and Shenk 1988). CREB is similar or identical to the factor ATF (activating transcription factor|, which binds to the identical early gene promoter sites and can activate transcription of early gene templates in vitro (Hurst and Jones 1987; K.A.W. Lee et al. 1987; Lin and Green 1988).

The early genes have been studied extensively by mutational analysis of transfected plasmid DNAs containing early gene promoters. In general, mutations that give rise to a decrease in E1A-induced transcription also lead to a similar reduction in basal transcription (Berk 1986). This approach has revealed that CRE-like sequences are located within domains required for optimal expression of the E2, E3, and E4 transcriptional control regions (Imperiale et al. 1985; Leff et al. 1985; Murthy et al. 1985; Zajchowski et al. 1985; Gilardi and Perricaudet 1986; Garcia et al. 1987; Hanaka et al. 1987; Lee and Green 1987). However, individual deletions that affect transcription do not render the target gene completely uninducible by E1A, suggesting that there may be several sites in the promoter at which E1A can act, either directly or indirectly, or that E1A somehow acts on a total transcription complex composed of a number of factors. Interestingly, when DNA fragments of $170 \mathrm{bp}$ (Gilardi and Perricaudet 1986) or 100 bp (Lee and Green 1987) containing E4-specific CRE-like sequences were appended to a non-E1A-responsive target gene, the hybrid constructs were stimulated by ElA proteins in a short-term transfection assay.

We were intrigued by the fact that, with the exception of the E1B gene, there are CRE-like sequences within all of the early gene 5 '-flanking domains, including the E1A gene (Hardy and Shenk 1988). We wondered whether the CRE-like sequences, or other potential cAMP-responsive sequences in the adenovirus early gene promoters, might confer cAMP responsiveness in vivo. We were also interested in determining whether there is any functional relationship between cAMP responsiveness, and E1A-regulated transcription. To pursue these questions, we have examined the effects of cAMP on transcription of the E4, E1A, and E1B genes during infection with adenovirus. We have found that CAMP can act in synergy with ElA to induce transcription of the E4 and E1A genes during infection. We have also observed induction of the E1B gene by CAMP, but cAMP did not act in synergy with E1A in this case. Our data establish a functional connection between E1A and events triggered by cAMP and suggest that E1A may interact with targets of the cAMP-signaling pathway to activate transcription of at least some of the early genes.

\section{Results}

\section{Induction of adenovirus early gene mRNAs by cAMP}

The effects of cAMP on early gene expression were examined in the context of viral infection. Introduction of viral DNA by infection allowed control of relative genome copy number and ensured the proper physical state of the DNA. In addition, this approach permitted analysis of each of the early genes at the same time after treatment of cells with cAMP analogs, so that their coordinate regulation could be followed and valid comparisons made. The use of viral mutants made it possible to identify a viral function (E1A) whose action influenced responsiveness to cAMP (see below).

In preliminary experiments, the cell line in which viral genes responded most strongly to analogs of cAMP was the mouse lymphoma line S49 (Horibata and Harris 1970). In the absence of cAMP analogs, ElA mRNAs appeared in the cytoplasm of $S 49$ cells by $5 \mathrm{hr}$ postinfection (the earliest time point tested). Viral DNA replication was first detected at $30-36 \mathrm{hr}$ postinfection (data not shown). The effects of cAMP analogs on expression of the early genes were examined during the period 12-24 hr postinfection, before the onset of viral DNA replication. ElA protein was active during this time; mRNAs encoded by the early genes E1A, E1B, E2A, and E4 were expressed in an ElA-dependent manner in the absence of CAMP analogs (Figs. 2, 5, and 7, and data not shown).

\section{E4 mRNA accumulation is induced by cAMP}

First, we examined the effects of dibutyryl cAMP $\left(\mathrm{Bt}_{2} \mathrm{cAMP}\right)$ on expression of mRNAs encoded by the E4 gene. There are four CRE-like sequences in the E4 promoter region. They are located at $-46,-163,-229$, and -260 , relative to the E4 cap site (Hardy and Shenk 1988). The two most distal sites are located in the inverted terminal repeat of the viral genome.

Exponentially growing S49 cells were infected with phenotypically wild-type adenovirus (dl309) at a multiplicity of infection (moi) of $20 \mathrm{pfu} / \mathrm{cell}$ and plated at a density of $5 \times 10^{5}$ cells $/ \mathrm{ml}$. Control and $\mathrm{Bt}_{2} \mathrm{cAMP}$. treated cells were harvested at 12 and $24 \mathrm{hr}$ postinfection. For the cells harvested at $12 \mathrm{hr}$ postinfection, treatment with $\mathrm{Bt}_{2} \mathrm{cAMP}$ ( $1 \mathrm{mM}$ in all cases) was for the final 4 or $2 \mathrm{hr}$ prior to harvesting. For the cells harvested at 24 hr postinfection, treatment with $\mathrm{Bt}_{2} \mathrm{cAMP}$ was for the final 5,3 , or $1 \mathrm{hr}$ prior to harvesting. For the cells harvested at $24 \mathrm{hr}$ postinfection, treatment with $\mathrm{Bt}_{2}$ cAMP was for the final 5,3 , or $1 \mathrm{hr}$ prior to harvesting. Cytoplasmic RNAs were isolated and analyzed for E4 mRNA by RNase protection (Melton et al. 1984). The results are shown in Figure 1. Addition of $\mathrm{Bt}_{2} \mathrm{CAMP}$ to infected cells produced a rapid 15 -fold increase in the level of cytoplasmic mRNAs encoded by the $\mathrm{E} 4$ gene. The control and induced levels of E4 mRNAs were higher at $24 \mathrm{hr}$ postinfection than at $12 \mathrm{hr}$ postinfection. This was probably due to the fact that transcription of the $\mathrm{E} 4$ gene was increasing during this time under the control of ElA. Identical results were obtained with the analog 8-bromo cAMP. The level of induction by 8 -bromo cAMP was as great as that observed with $\mathrm{Bt}_{2} \mathrm{CAMP}$ (not shown), confirming the specificity of cAMP for the effect. Induction of E4 mRNAs was also observed in wild-type virus-infected K-562 cells, a human lymphoid cell line, and wild-type virus-infected HepG2 cells, a human hepatoma cell line (not shown). 


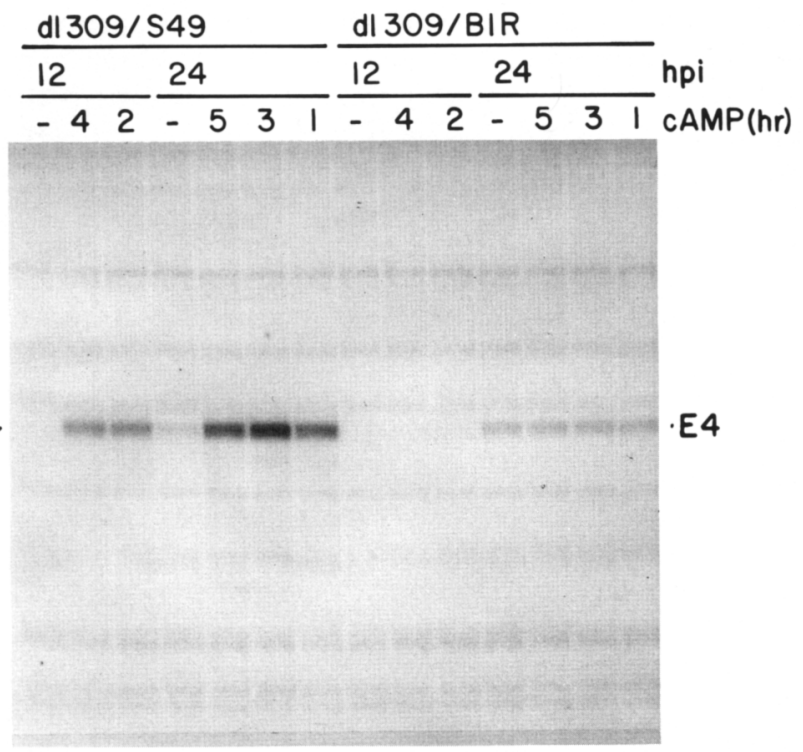

Figure 1. Effect of $\mathrm{Bt}_{2} \mathrm{cAMP}$ on E4 mRNA in S49 cells or B1R cells infected with dl309. S49 cells or B1R cells were infected with wild-type $d 1309$ and harvested 12 or $24 \mathrm{hr}$ later. Treatments with $1 \mathrm{mM} \mathrm{Bt}_{2} \mathrm{cAMP}$ were for the times indicated prior to harvesting. Cytoplasmic RNA isolation and analysis by RNase protection were performed as described in Materials and methods. The probe for the RNase protection assay was synthesized from a plasmid containing an Ad5 HindIII fragment spanning 89.1-97.1 map units, cloned into the vector pGEM2. The plasmid was linearized with SmaI and transcribed with T7 RNA polymerase in the presence of [ $\left.{ }^{32} \mathrm{P}\right] \mathrm{UTP}$. The resulting ${ }^{32}$ P-labeled RNA hybridized specifically with the 3' terminus of the E4 mRNAs (Halbert et al. 1985) RNase-resistant products were analyzed by electrophoresis through a $5 \%$ polyacrylamide gel containing $7 \mathrm{~mm}$ urea, and visualized by autoradiography. The data were quantified using a Bio-Rad model 620 video densitometer. (hpi) Hours postinfection; [cAMP ( $\mathrm{hr})] \mathrm{Bt}_{2} \mathrm{cAMP}(\mathrm{hr})$.

The known effects of cAMP in mammalian cells are mediated by activation of the cAMP-dependent protein kinase. Several cell lines deficient in CAMP-dependent protein kinase have been shown to be unresponsive to intracellular cAMP (for review, see Gottesman 1980). The cell line B1R is a line derived from S49 cells that contains little detectable cAMP-dependent protein kinase and is unresponsive to cAMP analogs (Bourne et al. 1975; Coffino et al. 1975). B1R cells were infected in parallel with the parental S49 cells and treated with $\mathrm{Bt}_{2} \mathrm{CAMP}$. Figure 1 shows that expression of $\mathrm{E} 4 \mathrm{mRNAs}$ in B1R cells infected with wild-type d1309 is unaffected by $\mathrm{Bt}_{2} \mathrm{CAMP}$ addition. This is in good agreement with previously characterized effects of cAMP, which require functional cAMP-dependent protein kinase.

There are E1A-independent and E1A-dependent components to the induction of E4 mRNA accumulation by $c A M P$

E1A is known to regulate transcription positively from the E4 promoter (Berk 1986). Because we were investi- gating the potential role of CAMP in transcriptional control of the E4 gene, we performed the same type of experiment with a virus unable to produce functional E1A protein. This provided a way to separate the transcriptional effects of ElA from those of cAMP. Mutant d1343 contains an out-of-frame deletion in the $12 \mathrm{~S}$ and $13 \mathrm{~S} 5^{\prime}$ exons of the E1A gene. ElA-dependent transcriptional activation of the early genes is not observed in dl343-infected cells, and the virus is defective for growth (Hearing and Shenk 1985). S49 cells were infected with wild-type virus (dl309) or dl343 and harvested at $24 \mathrm{hr}$ postinfection. dl309 was introduced at a moi of $20 \mathrm{pfu} /$ cell, and dl343 was introduced at moi of 20 and $250 \mathrm{pfu} /$ cell. Treatment with $\mathrm{Bt}_{2} \mathrm{cAMP}$ was for the final 5, 3, or 1 hr prior to harvesting. The results are shown in the left two panels of Figure 2. In cells infected with $d 1343$ at moi of either 20 or $250 \mathrm{pfu} / \mathrm{cell}, \mathrm{E} 4 \mathrm{mRNAs}$ were induced approximately fivefold after a 3 -hr treatment with $\mathrm{Bt}_{2}$ cAMP. Clearly, E4 mRNA induction was independent of ElA in this case. Identical results were obtained with mutant d1312 (Jones and Shenk 1979b), which lacks most of the ElA-coding region (not shown). The overall level of both uninduced and induced expression of E4 mRNA in dl343 was about threefold greater at a moi of 250 than at a moi of $20 \mathrm{pfu} / \mathrm{cell}$. However, the moi had no effect on the magnitude of the induction by $\mathrm{Bt}_{2} \mathrm{cAMP}$ (approximately fivefold after a 3 -hr treatment, for moi of 20 and $250 \mathrm{pfu} / \mathrm{cell})$. This indicates that the magnitude of induction was not a function of genome copy number.

Figure 2 (rightmost panel) shows the results of a parallel infection with wild-type virus dl309. Because E4

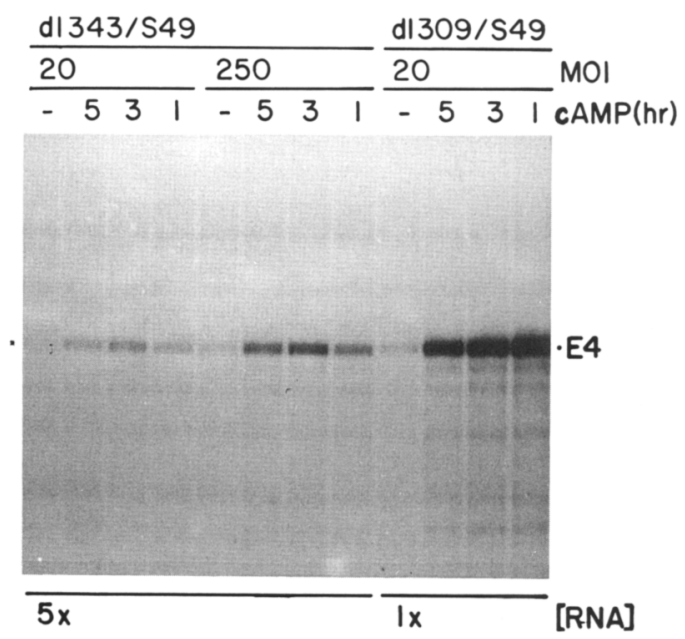

Figure 2. Analysis of $\mathrm{E} 4 \mathrm{mRNA}$ induction by $\mathrm{Bt}_{2} \mathrm{CAMP}$ in the absence or presence of E1A. S49 cells were infected with dl343 $\left(\mathrm{E} 1 \mathrm{~A}^{-}\right)$or $d 1309\left(\mathrm{El} \mathrm{A}^{+}\right)$and harvested $24 \mathrm{hr}$ later. Treatments with $1 \mathrm{mM} \mathrm{Bt} \mathrm{C}_{2} \mathrm{CAMP}$ were for the times indicated prior to harvesting. RNA isolation, analysis, and quantification were performed as described in Materials and methods. The probe used in the RNase protection assay was the same as that described in the legend to Fig. 1. (MOI) Multiplicity of infection; [cAMP (hr)] $\mathrm{Bt}_{2} \mathrm{cAMP}(\mathrm{hr}) ;(5 \times) 50 \mu \mathrm{g}$ cytoplasmic RNA per hybridization; $(1 \times) 10 \mu \mathrm{g}$ cytoplasmic RNA per hybridization. 
gene expression is controlled transcriptionally by E1A, the level of cytoplasmic E4 mRNAs in untreated cells was expected to be much higher in dl309- than in d1343-infected cells. To facilitate the comparison between $d 1309$ and dl343, we analyzed $10 \mu \mathrm{g}$ per RNA sample from d1309-infected cells and $50 \mu \mathrm{g}$ per RNA sample from dl343-infected cells. This is indicated in Figure 2 as $1 \times$ and $5 \times$. As expected, the level of E4 mRNAs in untreated cells was higher in wild-type virusthan in dl343-infected cells, due to the action of ElA /cf. untreated lanes from $d 1343$ and $d l 309$, noting the difference in the amount of RNA added to the assays). Interestingly, however, the magnitude of induction in wildtype virus-infected cells ( $>20$-fold) was much greater than in dl343-infected cells (fivefold). This difference must result from the action of E1A, or an E1A-activated viral or cellular product. Table 1 summarizes the data from Figure 2, showing the relative contributions of E1A and cAMP to the induction of E4 mRNAs. The effect of E1A and CAMP in combination was greater by a factor of 4 than the simple multiplication of effects of these two agents when introduced individually. Table 1 also contains the quantified results from two additional independent experiments that showed similar effects. Thus, E1A protein acts synergistically with cAMP to induce E4 mRNAs. From these data, it is clear that there are two components to the induction of E4 mRNAs by cAMP. One of these components is ElA independent, as was demonstrated in mutant $d 1343$, which lacks functional E1A protein. The other component is dependent on the presence of E1A.

\section{Involvement of E1A protein in the induction of E4 mRNA accumulation by $C A M P$}

We have shown that cAMP is a more potent inducer of E4 mRNAs in the presence of ElA protein than in its absence. What is the role of ElA in this process? The ElA promoter itself contains several CRE-like sequences. They are located at $-43,-329,-403$, and -435 , relative to the E1A cap site (Hardy and Shenk 1988; and data not shown). In a wild-type virus-infected cell, treatment with $\mathrm{Bt}_{2} \mathrm{cAMP}$ might result in an in- crease in the level of E1A mRNA, which could stimulate E4 gene transcription further through increased synthesis of ElA protein. Another possibility is that CAMP might trigger events in the cell that interact directly with the targets of E1A action. For instance, cAMP might raise the level and/or activity of transcription factors that ElA could then act upon to increase transcription. This effect could occur without a change in the level of E1A protein.

Accordingly, we looked for changes in E1A mRNA levels in response to $\mathrm{Bt}_{2} \mathrm{cAMP}$. For this series of experiments, we wanted to examine the events shortly following addition of $\mathrm{Bt}_{2} \mathrm{cAMP}$ to determine whether an induction of ElA mRNA by $\mathrm{Bt}_{2} \mathrm{CAMP}$ might precede induction of the E4 mRNAs. $\$ 49$ cells were infected with wild-type virus and harvested $24 \mathrm{hr}$ later. Treatments with $\mathrm{Bt}_{2}$ cAMP were for the final 15, 30, 60, and $120 \mathrm{~min}$ prior to harvesting. Figure 3 shows the results of an RNase protection assay in which $\mathrm{E} 4$ and E1A mRNAs were analyzed simultaneously. There was a clear induction of the $12 \mathrm{~S}$ and 13S E1A mRNAs (approximately fivefold after 60 and $120 \mathrm{~min}$ of treatment) that temporally paralleled the induction of the E4 mRNAs. Identical RNA samples that were analyzed for either E4 or E1A mRNAs separately gave the same results, demonstrating that the two probes for these mRNAs did not interfere with each other in the assay (not shown). From these data, it is apparent that E1A mRNAs do not appear in the cytoplasm fast enough to allow for an increase in E1A protein that could account for the extremely rapid induction of the E4 mRNAs (there is a detectable increase in $\mathrm{E} 4 \mathrm{mRNAs}$ as early as $15 \mathrm{~min}$ after treatment with $\mathrm{Bt}_{2} \mathrm{cAMP}$ ).

Next, we analyzed directly the level of E1A protein in wild-type virus-infected cells that were treated for 0,30 , or $60 \mathrm{~min}$ with $\mathrm{Bt}_{2} \mathrm{CAMP}$ prior to harvesting at $24 \mathrm{hr}$ postinfection. The purpose of this experiment was to determine whether there was an increase in total E1A protein during the first hour following treatment with $\mathrm{Bt}_{2} \mathrm{cAMP}$. It was during this period that the maximal synergistic effect on E4 mRNA levels occurred (Fig. 3). Figure 4 shows the results of Western blot analysis using an ElA-specific monoclonal antibody (Harlow et al.

Table 1. Induction of E4 $\mathrm{mRNA}$ by E1A and CAMP

\begin{tabular}{|c|c|c|c|c|c|}
\hline Experiment & Virus & $-\mathrm{Bt}_{2} \mathrm{cAMP}$ & $+\mathrm{Bt}_{2} \mathrm{cAMP}$ & (fold induction) & Synergy \\
\hline \multirow{2}{*}{$1^{b}$} & $\mathrm{E} \mathrm{A}^{-}$ & 1 & $5^{a}$ & $(5)$ & \multirow{2}{*}{ 4-fold } \\
\hline & $\mathrm{ElA}^{+}$ & 10 & $200^{c}$ & $(20)$ & \\
\hline \multirow{2}{*}{2} & E1A- & 1 & 4 & (4) & \multirow{2}{*}{ 3-fold } \\
\hline & $\mathrm{E} \mathrm{A}^{+}$ & 7 & 84 & (12) & \\
\hline \multirow{2}{*}{3} & E1A- & 1 & 3 & (3) & \multirow{2}{*}{3 -fold } \\
\hline & $\mathrm{E} 1 \mathrm{~A}^{+}$ & 10 & 90 & (9) & \\
\hline
\end{tabular}

Relative densitometry units.

a Greatest induction, observed after $3 \mathrm{hr}$ of $\mathrm{Bt}_{2} \mathrm{cAMP}$ treatment.

b Several exposures of the gel presented in Fig. 2 were analyzed with a Bio-Rad model 620 video densitometer. The lowest signal was arbitrarily set to 1 .

c Greatest induction, observed after $1-3 \mathrm{hr}$ of $\mathrm{Bt}_{2} \mathrm{cAMP}$ treatment. 
1986). There was no detectable change in the total level of ElA protein at 30 or $60 \mathrm{~min}$ after $\mathrm{Bt}_{2} \mathrm{cAMP}$ treatment. A titration experiment confirmed that the assay was sensitive enough to detect as little as a twofold change in E1A levels in this range of protein (not shown). This result confirmed that the E1A-dependent induction of E4 mRNAs, which was near or at its maximal level after $60 \mathrm{~min}$ of treatment with $\mathrm{Bt}_{2} \mathrm{CAMP}$, did not require an increase in total E1A protein. The fact that there was no increase in total ElA protein despite the increase in E1A mRNA could be due to several reasons. First, there may not have been enough time for newly synthesized protein to accumulate (the majority of the ElA mRNA induction was between 30 and $60 \mathrm{~min}$ after treatment). Second, the newly induced E1A protein may account for only a small percentage of the total and, thus, not affect total protein levels significantly. Regardless of these possibilities, the fact that total E1A protein did not increase after $60 \mathrm{~min}$ of $\mathrm{Bt}_{2} \mathrm{CAMP}$ treatment argues strongly that such an increase is not responsible for the synergistic effect on E4 transcription. Taken to-

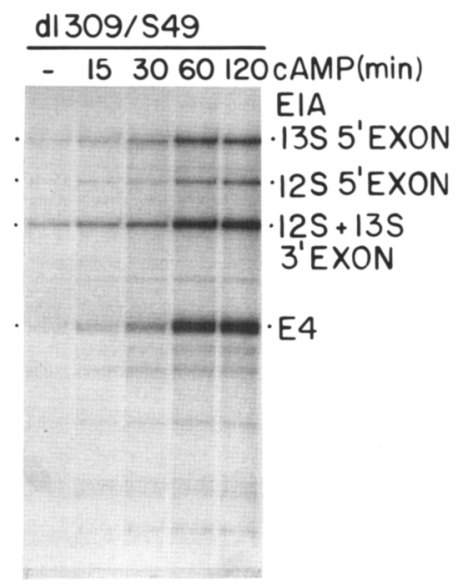

Figure 3. Analysis of E1A and E4 mRNAs in dl309-infected S49 cells soon after treatment with $\mathrm{Bt}_{2} \mathrm{CAMP}$. $\mathrm{S} 49$ cells were infected with $d 1309$ and harvested $24 \mathrm{hr}$ later. Treatments with $1 \mathrm{mM} \mathrm{Bt}_{2} \mathrm{cAMP}$ were for the times indicated prior to harvesting. Cytoplasmic RNA isolation and analysis were performed as described in Materials and methods. The E1A-specific probe was synthesized from a plasmid containing a PstI fragment spanning 0-5.1 map units of the Ad5 genome cloned into pGEM2. The plasmid was linearized with EcoRI and transcribed with T7 RNA polymerase in the presence of $\left[{ }^{32} \mathrm{P}\right] \mathrm{UTP}$. The resulting ${ }^{32} \mathrm{P}$-labeled RNA hybridized specifically with the alternatively spliced $12 S$ and $13 S$ E1A mRNAs. The RNase-resistant products produced were the $12 S$ and $13 S 5^{\prime}$ exons and the common $3^{\prime}$ exon shared by the $12 S$ and $13 S$ transcripts. This probe also hybridized with the $5^{\prime}$ terminus of mRNAs encoded by the E1B gene, but these data are not presented here for reasons of clarity. The E1B data are presented in another form in Fig. 7. The E4 probe was exactly as described in the legend to Fig. 1. RNase-resistant products were analyzed by electrophoresis through a $5 \%$ polyacrylamide gel containing $7 \mathrm{M}$ urea and visualized by autoradiography. The data were quantified using a Bio-Rad model 620 video densitometer. [cAMP (min)] dibutyryl $\mathrm{Bt}_{2} \mathrm{cAMP}$ (min).

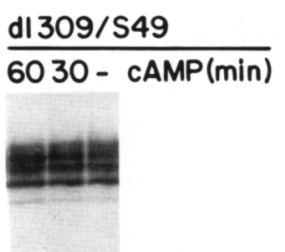

Figure 4. Western blot analysis of total E1A protein in dl309infected S49 cells soon after treatment with $\mathrm{Bt}_{2} \mathrm{cAMP}$. S49 cells were infected with $d 1309$ and harvested at $24 \mathrm{hr}$ postinfection. Treatments with $1 \mathrm{mM} \mathrm{Bt}{ }_{2} \mathrm{cAMP}$ were for the times indicated prior to harvesting. Samples (20 $\mu \mathrm{g}$ protein) of nuclear extracts (Dignam et al. 1983) were electrophoresed through an SDSpolyacrylamide gel, transferred to nitrocellulose, and probed with the E1A-specific monoclonal antibody M73 (Harlow et al. 1986), as described in Materials and methods. [cAMP (min)] $\mathrm{Bt}_{2} \mathrm{cAMP}(\mathrm{min})$.

gether, the data in Figures 3 and 4 strongly suggest that preexisting E1A acted in synergy with events triggered by the addition of $\mathrm{Bt}_{2} \mathrm{CAMP}$ to induce transcription of the $\mathrm{E} 4$ gene.

Finally, isolated nuclei were saved from the experiment presented in Figure 3 and used to generate ${ }^{32} \mathrm{P}$-labeled in vitro runoff products in order to examine the relative transcription rates of the E1A and E4 genes following stimulation with $\mathrm{Bt}_{2} \mathrm{CAMP}$. These data are presented in Table 2. Consistent with the analysis of cytoplasmic RNA, there was a rapid increase in E4 transcription 16-fold after a 15-min treatment and 20-fold after a 60-min treatment). The E1A gene was induced fivefold after a 60 -min treatment, and there may have been a slight induction after $15 \mathrm{~min}$ of treatment. We also observed a modest increase in actin gene transcription; however, the magnitude of this effect was small compared with E1A and E4. In control experiments, we observed no general increase in transcriptional activity in nuclei isolated from infected cells treated with $\mathrm{Bt}_{2} \mathrm{CAMP}$, compared to infected cells not treated with $\mathrm{Bt}_{2} \mathrm{cAMP}$ (not shown). These data demonstrate that in wild-type virus-infected cells, induction of the $\mathrm{E} 4$ and E1A mRNAs by cAMP is due predominantly to an increase in the transcription rate of the E4 and ElA genes. Furthermore, they show that induction of the E4 gene is

Table 2. Transcription rate analysis

\begin{tabular}{|c|c|c|c|c|c|}
\hline \multirow[b]{2}{*}{ Gene } & \multicolumn{5}{|c|}{ Min after $\mathrm{Bt}_{2} \mathrm{cAMP}(1 \mathrm{mM})$} \\
\hline & - & 15 & 30 & 60 & 120 \\
\hline E1A & 1 & 1.5 & 3 & 5 & 4 \\
\hline E4 & 1 & 6 & 10 & 20 & 15 \\
\hline Actin & 1 & 1 & 1.5 & 2 & 1.5 \\
\hline
\end{tabular}

Relative densitometry units.

Isolated nuclei from wild-type virus-infected S49 cells were used for transcriptional rate analysis, as described in Materials and methods. Following autoradiography, the data were analyzed with a Bio-Rad model 620 video densitometer. 
extremely rapid, again suggesting that an increase in the total level of E1A protein is not required for the effect. The sensitivity of the in vitro runoff assay did not permit reliable analysis of early gene transcripts produced in dl343-infected cells, because transcription of the early genes is very low in the absence of E1A. We note, however, that the magnitude of the transcriptional induction in wild-type virus-infected cells was identical to the induction observed at the level of cytoplasmic RNA ( 20-fold for the E4 gene and E4 mRNA and 5-fold for the ElA gene and E1A mRNA). This fact argues that, because E1A is known to act at the level of transcription, the synergistic effect that we observed at the level of cytoplasmic RNA is indeed a reflection of an effect at the level of transcription.

\section{Control of E1A mRNAs by CAMP is similar to control of $E 4$ mRNAs}

Like the E4 gene, the E1A gene itself is under transcriptional control of E1A protein during infection. Because the E1A mRNAs were observed to be induced by treatment with $\mathrm{Bt}_{2} \mathrm{CAMP}$, we wondered whether the magnitude of this induction was subject to the same dependence on E1A protein as was shown for the E4 mRNAs. Again, we analyzed cytoplasmic RNA from $\$ 49$ cells infected with wild-type virus or the mutant dl343. In this case, we used the phenotypically wild-type virus $d 1310$. dl310 contains an in-frame deletion in the $3^{\prime}$ exon of the ElA gene that allowed it to be distinguished from the $3^{\prime}$ exon of $d 1343$ in an RNase protection assay. This virus was chosen for convenient analysis of subsequent coinfection experiments (see below). The deletion in the $3^{\prime}$ exon of $d l 310$ does not affect its ability to activate transcription of the early genes, and the virus grows to wildtype levels (Jones and Shenk 1979b).

The E1A promoter in $d 1343$ is intact and functional, and the transcript produced is appropriately processed into the expected $12 \mathrm{~S}$ and $13 \mathrm{~S}$ mRNAs. The out-offrame deletion in the $5^{\prime}$ exon that gives rise to the $\mathrm{mu}$ tant phenotype produces an altered pattern of RNase-resistant products for the $12 \mathrm{~S}$ and $13 \mathrm{~S} 5^{\prime}$ exons in the RNase protection assay. The $3^{\prime}$ exon is unaffected, however, and can be analyzed quantitatively as a measure of cytoplasmic E1A mRNA levels. Figure 5 (left two panels) shows the results of a representative RNase protection assay using a probe specific for the E1A mRNAs, as well as the $5^{\prime}$ terminus of the E1B mRNAs. Like wildtype d1309, E1A mRNAs were induced in wild-type dl310-infected cells treated for various times with $\mathrm{Bt}_{2} \mathrm{cAMP}$ (a maximum of $\sim 10$-fold in this experiment). However, only a two- to threefold induction of the $d 1343$ E1A transcripts was observed. Therefore, the magnitude of induction by $\mathrm{Bt}_{2} \mathrm{cAMP}$ was greater in the presence of ElA than in its absence. This result was strikingly similar to our results with the E4 mRNA presented above. Table 3 shows the quantified results of the experiment shown in Figure 5, as well as two additional independent experiments.
E1A $m R N A$ from $\mathrm{dl} 343$ is induced maximally by cAMP in the presence of functional E1A proteins provided in trans

The observation that functional ElA protein is required for maximal induction of $\mathrm{E} 1 \mathrm{~A}$ mRNAs by $\mathrm{Bt}_{2} \mathrm{CAMP}$ allowed us to predict that we could increase the magnitude of the induction in dl343 by providing functional E1A in trans. To test this prediction, we coinfected dl343 with wild-type $d 1310$. $\$ 49$ cells were infected with either $d 1310$ or $d 1343$ alone at a moi of $20 \mathrm{pfu} / \mathrm{cell}$, or with a mixture of the two viruses at moi of either 10 or $20 \mathrm{pfu} / \mathrm{cell}$ (total moi of 20 and $40 \mathrm{pfu} / \mathrm{cell}$, respectively). Figure 5 shows the results of this experiment. Clearly, the E1A mRNAs encoded by dl343 were induced maximally when in the presence of wild-type virus producing functional E1A protein. The effect is evidenced by the behavior of the E1A $3^{\prime}$ exon encoded by dl343. When dl343 was infected alone, there was a two- to threefold induction by $\mathrm{Bt}_{2} \mathrm{CAMP}$ after $3 \mathrm{hr}$ of treatment. However, when in the presence of wild-type $d 1310$ producing functional ElA protein, the 3' exon encoded by $d 1343$ was induced $\sim 10$-fold. These data demonstrate that the lack of induction of E1A mRNA when $d 1343$ was infected alone was not due to an inherent instability of the mRNAs carrying the deletion because in the presence of ElA protein, these mRNAs were equally inducible as wild-type E1A mRNAs. The induction was also not due to an effect of genome copy number, because the effect was seen for infections whose total moi was either 20 (dl310 alone, dl343 alone, coinfection of $10+10 \mathrm{moi}$ ) or $40 \mathrm{pfu} / \mathrm{cell}$ (coinfection of $20+20 \mathrm{moi}$ ). Furthermore, E1A mRNAs from cells infected with $d 1343$ alone at a moi of $250 \mathrm{pfu} / \mathrm{cell}$ were not induced to a greater extent than observed at lower mois (data not shown). This argues against the possibility that induction by $\mathrm{Bt}_{2} \mathrm{CAMP}$ depended on titrating out a negatively acting transcription factor. We conclude that ElA protein acting in trans is required for maximal induction of E1A mRNAs by $\mathrm{Bt}_{2} \mathrm{cAMP}$.

Does ElA act directly in potentiating induction by cAMP, or does it work through the induction of another viral early gene product? To answer this question, S49 cells were infected with adenovirus early gene mutants dl313 (Jones and Shenk 1979b), dl339 (Logan et al. 1984), d1802 (Rice and Klessig 1985), dl327 (Thimmappaya et al. 1982), and d1366 (Halbert et al. 1985) and treated with $\mathrm{Bt}_{2} \mathrm{cAMP}$. These viruses contain large deletions in the coding regions of early genes E1B (dl313 and dl339), E2A (dl802), E3 (dl327), and E4 (dl366). Cytoplasmic RNA was analyzed for induction of E1A mRNA (Fig. 6). A strong induction was observed for each mutant. In parallel, wild-type infected cells showed an identical induction; only the E1A- virus $d 1343$ responded weakly to cAMP (not shown; see also Fig. 5, left two panels). Therefore, the role of E1A in potentiating induction by $\mathrm{Bt}_{2} \mathrm{cAMP}$ does not require these other early gene products. We did not test mutants of the E2B gene, which encodes the viral DNA polymerase and terminal protein. These proteins are involved in viral DNA repli- 


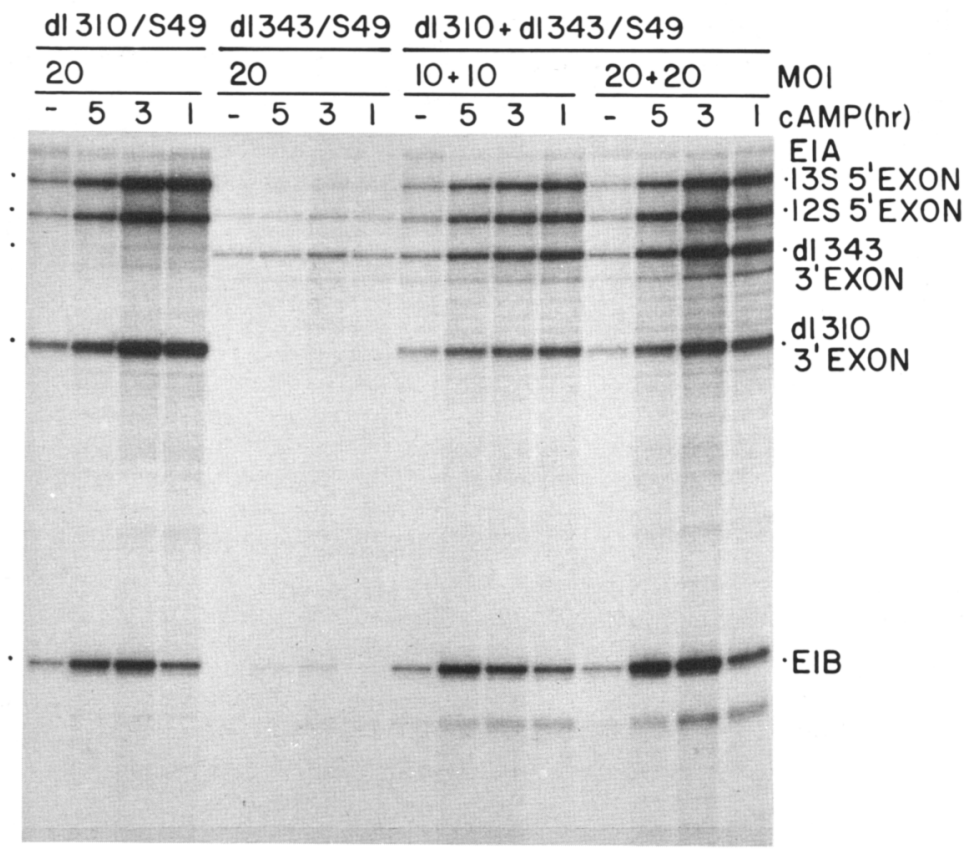

Figure 5. Effect of E1A protein on induction of E1A mRNAs by $\mathrm{Bt}_{2} \mathrm{cAMP}$. $\mathrm{S} 49$ cells were infected with $d 1310$ at a moi of 20 first group of four lanes; dl343, at a moi of 20 second group of four lanes; dl310 plus dl343, each at a moi of 10 third group of four lanes; $d l 310$ plus $d 1343$, each at a moi of 20 fourth group of four lanes. Cells were harvested at $24 \mathrm{hr}$ postinfection for cytoplasmic RNA isolation and analysis. Treatments with $1 \mathrm{mM} \mathrm{Bt}_{2} \mathrm{cAMP}$ were for the times indicated prior to harvesting. Analysis of cytoplasmic RNA was performed as described in Materials and methods. The E1A/E1B probe was used as described in the legend to Fig. 3. For the E1A mRNAs produced by $d 1343$ (see the second group of four lanes|, the small out-of-frame deletion in the $12 S$ and $13 S$ ' exons was recognized inefficiently by RNase $\mathrm{A}$ and $\mathrm{Tl}$ in the RNase protection assay. This produced a faint $d 134313 \mathrm{~S} 5^{\prime}$ exon signal due to partial cleavage of this exon. For $d 1343$, the band running in the position of the $12 \mathrm{~S} 5^{\prime}$ exon is a mixture of the cleaved $d 134313 S 5^{\prime}$ exon and the uncleaved $12 S$ $5^{\prime}$ exon. The band running just below the $3^{\prime}$ exon is the result of partial cleavage of the dl343 $12 \mathrm{~S}^{\prime}$ exon. The structure of the $3^{\prime}$ exon was not affected by the deletion in $d 1343$ and produced the expected product. The 3' exon was used for quantification of the results. RNase-resistant products were analyzed by electrophoresis through a $5 \%$ polyacrylamide gel containing $7 \mathrm{M}$ urea and visualized by autoradiography. The data were quantified using a Bio-Rad model 620 video densitometer. (MOI) Multiplicity of infection. [cAMP (hr)] Bt ${ }_{2} \mathrm{cAMP}$ (hr). cation, and all of our experiments were carried out prior to the onset of DNA replication in S49 cells, which starts between 30 and $36 \mathrm{hr}$ postinfection/data not shown). It is unlikely that either of these proteins plays a direct role in transcriptional regulation prior to the onset of DNA replication. We have seen a clear induction of ElA mRNAs by $\mathrm{Bt}_{2} \mathrm{cAMP}$ as early as $5 \mathrm{hr}$ postinfection, a time when we were unable to detect mRNAs encoded by any other of the E1A-responsive genes (data not shown). This also suggests that E1A alone was responsible for the effect.

\section{Induction of E1B $m R N A$ by $c A M P$ does not require E1A}

In wild-type virus-infected cells, we noticed that mRNAs encoded by the E1B gene were also induced by $\mathrm{Bt}_{2} \mathrm{cAMP}$ (Fig. 5). In vitro runoff experiments using isolated nuclei confirmed that this effect was at the level of transcription (not shown). Interestingly, there are no recognizable CRE-like sequences upstream of the E1B mRNA start site that would have led us to predict this effect. We pursued this observation in order to determine whether control of the E1B gene by $\mathrm{Bt}_{2} \mathrm{CAMP}$ might be different from control of the E4 and E1A genes. S49 cells were infected with wild-type $d 1309$ or $d 1343$ and harvested 24 hr later. dl309 was introduced at a moi of $20 \mathrm{pfu} / \mathrm{cell}$, and $d l 343$ was introduced at moi of 20 and $250 \mathrm{pfu} / \mathrm{cell}$. Treatment with $\mathrm{Bt}_{2} \mathrm{CAMP}$ was for the final 5,3 , or $1 \mathrm{hr}$ prior to harvesting. Despite the dependence on E1A protein observed for induction of the E4 and E1A mRNAs,

Table 3. Induction of E1A $m R N A$ by E1A and $c A M P$

\begin{tabular}{|c|c|c|c|c|c|}
\hline Experiment & Virus & $-\mathrm{Bt}_{2} \mathrm{cAMP}$ & $+\mathrm{Bt}_{2} \mathrm{cAMP}$ & (fold induction) & Synergy \\
\hline $1^{\mathbf{a}}$ & $\begin{array}{l}\text { ElA }^{-} \\
\text {ElA }\end{array}$ & $\begin{array}{l}1 \\
3\end{array}$ & $\begin{array}{r}3 \\
30\end{array}$ & $\begin{array}{r}(3) \\
(10)\end{array}$ & 3.3-fold \\
\hline 2 & $\begin{array}{l}\mathrm{ElA}^{-} \\
\mathrm{E}^{+} A^{+}\end{array}$ & $\begin{array}{l}1 \\
3\end{array}$ & $\begin{array}{r}2 \\
18\end{array}$ & $\begin{array}{l}(2) \\
(6)\end{array}$ & 3-fold \\
\hline 3 & $\begin{array}{l}\text { ElA }^{-} \\
\text {ElA }^{+}\end{array}$ & $\begin{array}{l}1 \\
3\end{array}$ & $\begin{array}{r}2 \\
24\end{array}$ & $\begin{array}{l}(2) \\
(8)\end{array}$ & 4-fold \\
\hline
\end{tabular}

Relative densitometry units.

Data from Fig. 5 were quantified using a Bio-Rad model 620 video densitometer. The lowest signal was arbitrarily set to 1. 


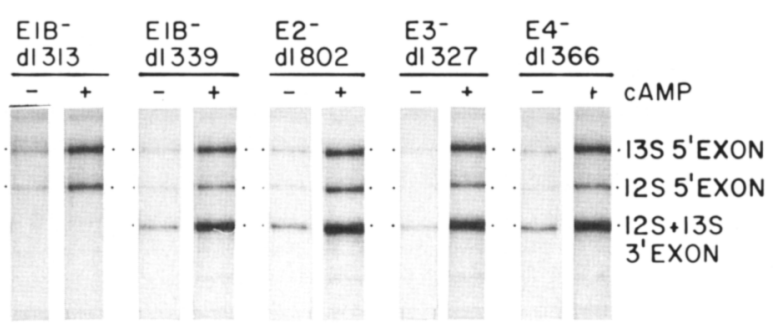

Figure 6. Analysis of E1A mRNA induction by $\mathrm{Bt}_{2} \mathrm{CAMP}$ in adenovirus early gene mutants. $S 49$ cells were infected with the indicated viruses and harvested $24 \mathrm{hr}$ later. Treatment with 1 $\mathrm{mM} \mathrm{Bt}{ }_{2} \mathrm{cAMP}$ was for $1 \mathrm{hr}$ prior to harvesting. RNA isolation and analysis was performed as described in Materials and methods. The probe used was the same as that described in the legend to Fig. 3. In this case, only the data for ElA are presented. The deletion in dl313 produces a foreshortened ElA $3^{\prime}$ exon. The RNase-resistant product corresponding to the $3^{\prime}$ exon of $d l 313$ migrated well ahead of the other bands and is not shown for reasons of clarity. RNase-resistant products were analyzed by electrophoresis through a $5 \%$ polyacrylamide gel containing $7 \mathrm{M}$ urea and visualized by autoradiography. The data were quantified using a Bio-Rad model 620 video densitometer. (cAMP) $\mathrm{Bt}_{2} \mathrm{cAMP}$.

E1B mRNA induction occurred efficiently even in dl343-infected cells (i.e., in the absence of functional ElA protein). This is illustrated in Figure 7. To facilitate the comparison between $d 1309$ and $d 1343$, two different exposures of the same gel are presented. Figure 7 shows that the time course and extent of induction of the E1B mRNAs were essentially the same in a wild-type or an E1A- background. At $24 \mathrm{hr}$ postinfection, the level of E1B mRNA in untreated cells was higher in wild-type dl309 than in dl343. This was due to the effect of ElA, which regulates the E1B gene transcriptionally. However, unlike the E4 and E1A mRNAs, addition of $\mathrm{Bt}_{2} \mathrm{CAMP}$ induced the E1B mRNAs from dl309 and dl343 equally (10-fold in the case of $d 1343$ at moi of 20 and 250 $\mathrm{pfu} / \mathrm{cell}$ and 8-fold in the case of dl309 at a moi of 20 $\mathrm{pfu} / \mathrm{cell})$. This demonstrates that the induction of E1B

Figure 7. Analysis of $\mathrm{E} 1 \mathrm{~B}$ mRNA induction by $\mathrm{Bt}_{2} \mathrm{CAMP}$ in the absence or presence of ElA. $S 49$ cells were infected with dl343 $\left(\mathrm{E}^{\left.-1 \mathrm{~A}^{-}\right)}\right.$or $d \mathrm{dl309}\left(\mathrm{E} 1 \mathrm{~A}^{+}\right)$and harvested $24 \mathrm{hr}$ later. Treatments with $1 \mathrm{mM} \mathrm{Bt}_{2} \mathrm{cAMP}$ were for the times indicated prior to harvesting. RNA isolation and analysis were performed as described in Materials and methods. The probe used was the same as that described in the legend to Fig. 3. In this case, only the data for E1B are presented. RNase-resistant products were analyzed by electrophoresis through a $5 \%$ polyacrylamide gel containing $7 \mathrm{M}$ urea and visualized by autoradiography. The data were quantified using a Bio-Rad model 620 video densitometer. (MOI) Multiplicity of infection. [cAMP (hr)] Bt ${ }_{2} \mathrm{cAMP}(\mathrm{hr})$.
mRNA by $\mathrm{Bt}_{2} \mathrm{CAMP}$ was independent of the action of E1A. This is in contrast to E4 and ElA mRNA regulation, on which the effects of E1A and CAMP were shown to be synergistic.

We also noted that the kinetics of induction for the E1A and E1B mRNAs were different (Figs. 5 and 7). Whereas ElA mRNA elevation was maximal between 1 and $3 \mathrm{hr}$ after exposure to $\mathrm{Bt}_{2} \mathrm{CAMP}, \mathrm{E} 1 \mathrm{~B}$ mRNA approached a maximal level more slowly. The maximal level of E1B mRNAs was observed repeatedly to occur at 3-5 hr after treatment with $\mathrm{Bt}_{2} \mathrm{cAMP}$ (we did not examine longer time points). We conclude that the ElB gene is regulated differently than the E1A and E4 genes in terms of its response to cAMP. It is interesting to note that the E1B gene also responds to E1A differently than the other early adenovirus gene (Wu et al. 1987).

\section{Discussion}

We have examined the effects of cAMP on transcriptional regulation of the adenovirus early genes E4, E1A, and E1B. We have observed that in cells infected with wild-type adenovirus, cAMP activates transcription of these genes, which are normally under control of the E1A proteins. Furthermore, we have found that cAMP acts in synergy with E1A to induce maximally transcription of the E1A and E4 genes.

There are several possibilities to explain how cAMP might influence transcription of adenovirus genes in a manner that depends on E1A protein. For instance, cAMP could act by binding directly to one or more components of the transcriptional machinery that E1A is acting upon also (i.e., to one or more transcription factors). cAMP could also act by binding directly to E1A, thereby increasing its activity. However, because the induction of E4 mRNA by cAMP was blocked in cells that are deficient in CAMP-dependent protein kinase, it is more likely that protein phosphorylation is an important mediator in this process. We favor a hypothesis in which increasing the intracellular level of cAMP leads to an increase in cAMP-dependent protein kinase activity which, in turn, results in a stimulation of E1A-de-

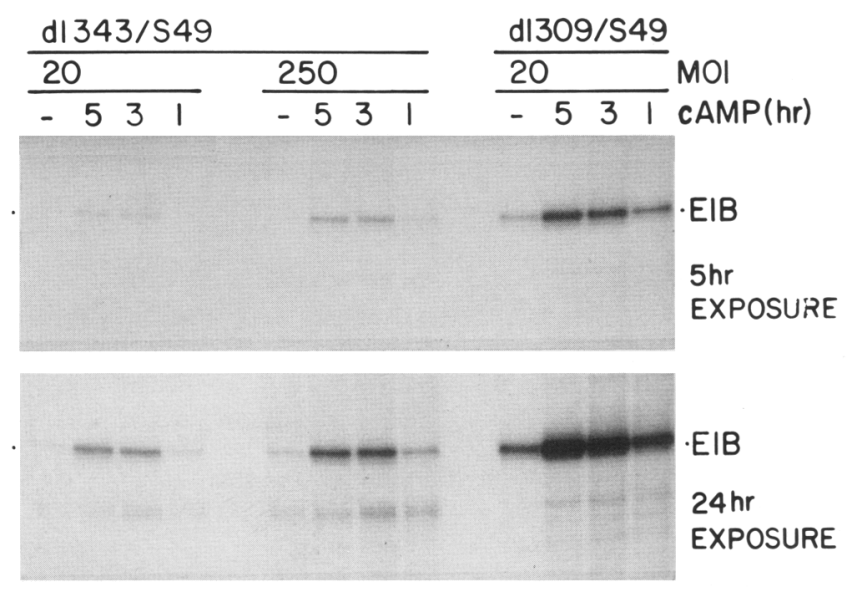


pendent transcription. The cAMP-dependent protein kinase might act by phosphorylating the E1A protein directly, thereby increasing its activity as a transcriptional regulator. Alternatively, the kinase might trigger activation of one or more specific transcription factors that E1A could then act upon. This could be accomplished through direct phosphorylation of the factors or might require intermediate steps.

What is the role of the CRE-like sequences in the observed transcriptional effects on the E4 and E1A genes? Unpublished results from our laboratory indicate that S49 cells contain the nuclear protein CREB, which has been shown to be involved in the induction of somatostatin gene transcription by cAMP (Montminy and Bilezikjian 1987). It is likely that CREB also plays a role in transcription of the adenovirus early genes, considering the correlation between the results reported here and those reported earlier (Hardy and Shenk 1988) that CREB recognizes the CRE-like sequences upstream of the E4 and E1A genes in an in vitro binding assay. However, this may not be the entire story. Piette et al. (1988) have reported that the transcription factor AP-1 is induced in NIH-3T3 cells by treatment with $\mathrm{Bt}_{2} \mathrm{cAMP}$. The sequence in the collagenase promoter recognized by AP-1 (TGACTCA; Lee et al. 1987) is very similar to the core binding site for CREB (TGACGTCA; Montminy and Bilezikjian 1987). Using in vitro competition analysis, we have developed evidence that AP-1 may also bind to CREB-binding sites (S. Hardy, U. Mueller, and T. Shenk, unpubl.). Consistent with this is the finding that TPA, a known inducer of AP-1 activity, also induces transcription of the E4 gene (D. Engel and T. Shenk, unpubl.). The effect of cAMP on the activity of these factors is currently under investigation.

It is likely that transcription factors responding to cAMP are not completely inactive in the absence of an increase in intracellular cAMP concentration. Their level of activity might be determined, in part, by the basal level of cAMP-dependent protein kinase activity in the cell. Presumably, this is also true for cells that do not respond to exogenous cAMP but that have active cAMP-dependent protein kinase. Given this, it is reasonable to consider that E1A would also be able to act on these factors in the absence of stimulation by cAMP. This condition describes a normal wild-type infection by adenovirus. Conceivably, E1A, at least in part, activates transcription through the action of specific transcription factors whose level of activity is influenced by cAMPdependent protein kinase. ElA could activate transcription by increasing the activity of these as well as other non-cAMP-dependent factors.

Several facts argue against the possibility that the transcriptional effects observed were a secondary effect of an increase in viral genome copy number during the treatment with $\mathrm{Bt}_{2} \mathrm{cAMP}$. First, transcriptional activity of the genes was analyzed prior to the onset of viral DNA replication in S49 cells. Second, induction of ElA mRNAs by $\mathrm{Bt}_{2} \mathrm{cAMP}$, identical to that seen in wildtype-infected cells, was also observed for mutant $d 1802$ (Rice and Klessig 1985) (Fig. 6). This virus expresses E1A protein but is severely compromised for DNA replication due to a mutation in the gene encoding the $72-\mathrm{kD}$ DNA-binding protein. Finally, the rapid nature of the transcriptional induction of the $\mathrm{E} 4$ gene argues against an increase in genome copy number being involved.

In our experiments, the E1B gene was induced by cAMP, but in a manner that differed from the induction observed for the E4 and E1A genes. Unlike the E4 and ElA genes, induction of the E1B gene by cAMP appeared independent of the action of ElA. Conceivably, this could mean that factors responding to cAMP mediate basal transcription of the E1B gene (i.e., not induced by E1A). There are no recognizable CRE-like sequences just upstream of the E1B mRNA cap site, but it is possible that the CRE-like sequences upstream of the E1A gene are affecting E1B transcription.

Parks et al. (1988) have shown recently that the sequence CCCCAGGCC located at -169 to -161 , relative to the ElB cap site, is within a region protected in a DNase I footprint assay by HeLa cell extracts. This sequence is very similar to the sequence CCCCAGGCT in the SV40 enhancer involved in binding transcription factor AP-2 (Mitchell et al. 1987). AP-2 has been implicated recently in control of metallothionein $\mathrm{II}_{\mathrm{A}}$ transcription by cAMP (Imagawa et al. 1987). A series of viruses with deletions upstream of the E1B gene were used to define elements involved in control of the E1B gene by E1A. This study implicated the E1B gene TATA box in activation of E1B transcription by ElA (Wu et al. 1987). Perhaps the AP-2-like binding sequence (or another type of element responsive to cAMP) mediates basal transcription of the E1B gene, whereas the TATA box is involved in E1A-inducible transcription.

\section{Materials and methods}

Cells and viruses

S49 cells were obtained from the University of California at San Francisco Cell Culture Facility. B1R cells were a gift from Dr. Vincent Groppi (The Upjohn Company). S49 and B1R cells were grown in suspension in tissue-culture dishes, in Dulbecco's modified Eagle's media supplemented with $10 \%$ heat-inactivated horse serum (GIBCO). To produce virus stocks, wild-type $d 1309$ and wild-type $d 1310$ (Jones and Shenk 1979b) were propagated in HeLa cells. Mutant dl343 (Hearing and Shenk 1985) was propagated in 293 cells (Graham et al. 1977).

Viral infection and treatment with $B t_{2} c A M P$

Exponentially growing S49 or B1R cells at $\sim 1 \times 10^{6}$ cells $/ \mathrm{ml}$ were pooled and counted in a hemocytometer. The cells were centrifuged briefly and resuspended at a density of $5 \times 10^{6}$ cells $/ \mathrm{ml}$ in media containing $2 \%$ heat-inactivated horse serum. Virus was added to the appropriate multiplicity (in plaqueforming units per cell) and incubated for $1 \mathrm{hr}$ at $37^{\circ} \mathrm{C}$ with occasional resuspension of the cells. Infected cells were diluted to $5 \times 10^{5}$ cells $/ \mathrm{ml}$ in media supplemented with $10 \%$ heat-inactivated horse serum and aliquoted into individual tissue culture dishes for subsequent treatment with $\mathrm{Bt}_{2} \mathrm{CAMP}$ (BoehringerMannheim). At the appropriate times prior to harvesting, cells were treated with 0.01 culture volumes of freshly dissolved 100 $\mathrm{mM} \mathrm{Bt}{ }_{2} \mathrm{cAMP}$ in $50 \mathrm{mM}$ HEPES (pH 7.9) (final $\mathrm{Bt}_{2} \mathrm{cAMP}$ concentration, $1 \mathrm{mM}$ ). 


\section{Cytoplasmic RNA isolation and analysis}

Cells were harvested by centrifugation and washed twice in an excess of ice-cold PBS. Cytoplasmic RNA isolation was according to Farrell et al. (1979). The RNAs were analyzed by ribonuclease protection (Melton et al. 1984). The E4-specific probe was synthesized from a plasmid containing and Ad5 HindIII fragment spanning 89.1-97.1 map units cloned into the vector pGEM2 (Promega). The plasmid was linearized with SmaI and transcribed with T7 RNA polymerase (New England Biolabs) in the presence of [32P]UTP. The resulting ${ }^{32}$-labeled RNA hybridized specifically with the $3^{\prime}$ terminus of the E4 mRNAs (Halbert et al. 1985). The E1A/E1B-specific probe was synthesized from a plasmid containing a PstI fragment spanning 0-5.1 map units of Ad5 cloned into pGEM2. The plasmid was linearized with EcoRI and transcribed with T7 RNA polymerase in the presence of $\left.{ }^{32} \mathrm{P}\right] \mathrm{UTP}$. The resulting ${ }^{32} \mathrm{P}$-labeled RNA hybridized specifically with the alternatively spliced $12 \mathrm{~S}$ and 13 S E1A mRNAs and the $5^{\prime}$ terminus of the E1B mRNAs. RNase-resistant products were analyzed by electrophoresis through a $5 \%$ polyacrylamide gel containing $7 \mathrm{M}$ urea and visualized by autoradiography. The data were quantified using a Bio-Rad model 620 video densitometer.

\section{Transcriptional rate analysis using isolated nuclei}

Cells $\left(0.5 \times 10^{8}\right.$ to $\left.1.0 \times 10^{8}\right)$ were brought to $0^{\circ} \mathrm{C}$ by transferring them to chilled bottles in an ice-water bath. They were then centrifuged at $4^{\circ} \mathrm{C}$, washed twice in an excess of ice-cold PBS, and lysed in $1 \mathrm{ml}$ of lysis buffer $(10 \mathrm{~mm}$ Tris- $\mathrm{HCl}$ at $\mathrm{pH} 7.5$, $150 \mathrm{~mm} \mathrm{NaCl}, 1 \mathrm{~mm} \mathrm{MgCl}_{2}, 0.075 \%$ Triton X-100). Nuclei were pelleted for $5 \mathrm{~min}$ at $1000 \mathrm{rpm}$ in a Sorvall RC-3B centrifuge with a $\mathrm{H} 6000 \mathrm{~A}$ rotor. The supernatant was removed and saved for cytoplasmic RNA isolation and analysis. The pellet was washed in $1 \mathrm{ml}$ of lysis buffer, centrifuged as before, resuspended in $0.4 \mathrm{ml}$ of glycerol storage buffer (Groudine et al. 1981), and divided into $0.1-\mathrm{ml}$ aliquots. Nuclei were frozen in liquid $\mathrm{N}_{2}$ and stored at $-70^{\circ} \mathrm{C}$ until use. Transcription in vitro was according to Greenberg and Ziff (1984). Nuclei $\left(2 \times 10^{7}\right.$ in $0.1 \mathrm{ml}$ ) were thawed, mixed with $0.1 \mathrm{ml}$ of $2 \times$ reaction buffer [10 mM Tris- $\mathrm{Cl}$ ( $\mathrm{pH} 8), 5 \mathrm{~mm} \mathrm{MgCl}_{2}, 300 \mathrm{~mm} \mathrm{KCl}, 5 \mathrm{~mm}$ dithiothreitol (DTT), $1 \mathrm{mM}$ each ATP, CTP, GTP, and $200 \mu \mathrm{Ci}$ [32 P]UTP $(400 \mathrm{Ci} / \mathrm{mmole})]$, and incubated at $30^{\circ} \mathrm{C}$ for $30 \mathrm{~min}$. The reaction was stopped by addition of $10 \mu \mathrm{g}$ of DNase I (Worthington DPFF) at $30^{\circ} \mathrm{C}$ for $5 \mathrm{~min}$. Samples were treated with $50 \mu \mathrm{l}$ of a solution containing $50 \mathrm{mM}$ Tris- $\mathrm{Cl}(\mathrm{pH} 8), 5 \%$ SDS, $25 \mathrm{~mm}$ EDTA, and $1 \mathrm{mg} / \mathrm{ml}$ proteinase $\mathrm{K}$ at $37^{\circ} \mathrm{C}$ for 30 $\mathrm{min}$, and extracted twice with phenol/chloroform. RNA labeled with ${ }^{32} \mathrm{P}$ was separated from unincorporated nucleotides by gel filtration through a 5-ml Sephadex G-50 (med) column and precipitated with ethanol. The ${ }^{32} \mathrm{P}-1$ labeled RNA was hybridized to specific DNA segments immobilized on nitrocellulose in the form of slot blots. Conditions of hybridization and washing were according to Engel et al. (1985), except that the final wash step was in $0.2 \times \mathrm{SSC}, 0.1 \%$ SDS at $42^{\circ} \mathrm{C}$ for $2 \mathrm{hr}$. Following autoradiography, the data were quantified using a Bio-Rad model 620 video densitometer.

\section{Western blot analysis}

Nuclear extracts (Dignam et al. 1983) were prepared, and samples (20 $\mu$ g protein) were electrophoresed through an SDSpolyacrylamide gel, transferred to nitrocellulose, and probed with the E1A-specific monoclonal antibody M73 (Harlow et al. 1986). Filters were incubated with alkaline phosphatase-conjugated rabbit anti-mouse IgG (Sigma). Bands were visualized with 5-bromo-4-chloro-3-indolylphosphate and nitro blue tetrazolium (Sigma).

\section{Acknowledgments}

We especially wish to thank Uli Mueller for performing the Western blot analysis, and Dr. Jerome Schaack for providing plasmids used in RNase protection and for many helpful suggestions. We also thank Dr. Henry Bourne, Dr. Vincent Groppi, and Seth Jacob Engel for helpful discussions, and Dr. Mariano Garcia-Blanco and members of our laboratory for reading the manuscript critically. This investigation was supported by a grant from the National Institutes of Health (CA-38965), and by U.S. Public Health Service grant CA-08210 awarded by The National Cancer Institute, Department of Health and Human Services. D. Engel is the recipient of a National Research Service Award postdoctoral fellowship. S. Hardy is a predoctoral trainee of the National Institute of General Medical Sciences (GM-07388), and T. Shenk is an American Cancer Society Research Professor.

\section{References}

Berk, A.J. 1986. Adenovirus promoters and E1A transactivation. Annu. Rev. Genet. 20: 45-79.

Berk, A.J., F. Lee, T. Harrison, J. Williams, and P.A. Sharp. 1979. A pre-early adenovirus 5 gene product regulates synthesis of early viral messenger RNAs. Cell 17: 935-944.

Borrelli, E., R. Hen, and P. Chambon. 1984. Adenovirus-2 ElA products repress enhancer-induced stimulation of transcription. Nature 312: 608-612.

Bourne, H.R., P. Coffino, and G.M. Tomkins. 1975. Somatic genetic analysis of cyclic AMP action: Characterization of unresponsive mutants. J. Cell. Physiol. 85: 611-620.

Chatteriee, P.K., M. Burner, S.J. Flint, and M.L. Harter. 1988. DNA-binding properties of an adenovirus $289 \mathrm{R}$ ElA protein. EMBO I. 7: 835-841.

Coffino, P., H.R. Bourne, and G.M. Tomkins. 1975. Somatic genetic analysis of cyclic AMP action: Selection of unresponsive mutants. I. Cell. Physiol. 85: 603-610.

Dignam, J.D., R.M. Lebovitz, and R.G. Roeder. 1983. Accurate transcription initiation by RNA polymerase II in a soluble extract from isolated mammalian nuclei. Nucleic Acids Res. 11: $1475-1489$.

Engel, D.A., H. Samanta, M.E. Brawner, and P. Lengyel. 1985. Interferon action: Transcriptional control of a gene specifying a 56,000-Da protein in Ehrlich ascites tumor cells. Virology 142: 389-397.

Farrell, P.J., R.J. Broeze, and P. Lengyel. 1979. Accumulation of a mRNA and protein in interferon-treated Ehrlich ascites tumor cells. Nature 279: 523-525.

Ferguson, B., B. Krippl, O. Andrisani, N. Jones, H. Westphal, and M. Rosenberg. 1985. E1A 13S and 12S mRNA products made in $E$. coli both function as nucleus-localized transcription activators but do not directly bind DNA. Mol. Cell. Biol. 5: 2653-2661.

Garcia, J., F. Wu., and R. Gaynor. 1987. Upstream regulatory regions required to stabilize binding to the TATA sequence in an adenovirus early promoter. Nucleic Acids Res. 15: $8367-8385$.

Gilardi, P., and M. Perricaudet. 1986. The E4 promoter of adenovirus type 2 contains an E1A-dependent cis-acting element. Nucleic Acids Res. 14: 9035-9049.

Gottesman, M.M. 1980. Genetic approaches to cyclic AMP effects in cultured mammalian cells. Cell 22: 329-330.

Graham, F.L., J. Smiley, W.C. Russell, and R. Nairu. 1977. Characteristics of a human cell line transformed by DNA from human adenovirus type 5. J. Gen. Virol. 36: 59-72.

Greenberg, M.E. and E.B. Ziff. 1984. Stimulation of 3T3 cells 
induces transcription of the c-fos proto-oncogene. Nature 311: 433-438.

Greenberg, M.E., L.A. Greene, and E.B. Ziff. 1985. Nerve growth factor and epidermal growth factor induce rapid transient changes in proto-oncogene transcription in PC-12 cells. J. Biol. Chem. 260: 14101-14110.

Groudine, M., M. Peretz, and H. Weintraub. 1981. Transcriptional regulation of hemoglobin switching in chicken embryos. Mol. Cell. Biol. 1: 281-288.

Halbert, D.N., J.R. Cutt, and T. Shenk. 1985. Adenovirus early region 4 encodes functions required for efficient DNA replication, late gene expression, and host cell shutoff. $J$. Virol. 56: $250-257$

Hanaka, S., T. Nishigaki, P.A. Sharp, and H. Handa. 1987. Regulation of in vitro and in vivo transcription of early-region IV of adenovirus type 5 by multiple cis-acting elements. Mol. Cell. Biol. 7: 2578-2587.

Hardy, S. and T. Shenk. 1988. Adenoviral control regions activated by E1A and the cAMP response element bind the same factor. Proc. Natl. Acad. Sci. 85: 4171-4175.

Harlow, E., P. Whyte, B.R. Franza, Jr., and C. Schley. 1986. Association of adenovirus early-region 1A proteins with cellular polypeptides. Mol. Cell. Biol. 6: 1579-1589.

Hearing, P. and T. Shenk. 1985. Sequence-independent autoregulation of the adenovinus type 5 ElA transcription unit. Mol. Cell. Biol. 5: 3214-3221.

Hen, R., E. Borelli, and P. Chambon. 1985. Repression of the immunoglobulin enhancer by the adenovirus E1A products. Science 230: 1391-1394.

Hoeffler, W.K. and R.G. Roeder. 1985. Activation of transcription factor IIIC by the adenovirus ElA protein. Cell 53: $907-920$

Horibata, K. and A.W. Harris. 1970. Mouse myelomas and lymphomas in culture. Exp. Cell. Res. 60: 61-77.

Hurst, H.C. and N.C. Jones. 1987. Identification of factors that interact with the ElA-inducible adenovinus E3 promoter. Genes Dev. 1: 1132-1146.

Imperiale, M.J., R.P. Hart, and J.R. Nevins. 1985. An enhancerlike element in the adenovirus $\mathrm{E} 2$ promoter contains sequences essential for uninduced and ElA-induced transcription. Proc. Natl. Acad. Sci. 82: 381-385.

Jones, N. and T. Shenk. 1979a. An adenovirus type 5 early gene function regulates expression of other early viral genes. Proc. Natl. Acad. Sci. 76: 3665-3669.

- 1979b. Isolation of Ad5 host range deletion mutants defective for transformation of rat embryo cells. Cell 17: 683689.

Jones, N.C., P.W.J. Rigby, and E.B. Ziff. 1988. Trans-acting protein factors and the regulation of eukaryotic transcription: Lessons from studies on DNA tumor viruses. Genes Dev. 2: $267-281$

Ko, J.-L., B.L. Dalie, E. Goldman, and M.L. Harter. 1986. Adenovirus-2 early region 1A protein synthesized in Escherichia coli extracts indirectly associates with DNA. EMBO $I$. 5: $1645-1651$.

Kovesdi, I., R. Reichel, and J.R. Nevins. 1986a. Identification of a cellular transcription factor involved in E1A trans-activation. Cell 45: 219-228.

1986b. ElA transcription induction: Enhanced binding of a factor to upstream promoter sequences. Science 231: $719-722$.

Lee, K.A.W. and M.R. Green. 1987. A cellular transcription factor E4F1 interacts with an E1A-inducible enhancer and mediates constitutive function in vitro. $E M B O F$. 6: 13451353.

Lee, K.A.W., T.-Y. Hai, L. SivaRaman, B. Thimmappaya, H.C.
Hurst, N.C. Jones, and M.R. Green. 1987. A cellular protein, activating transcription factor, activates transcription of multiple ElA-inducible adenovirus early promoters. Proc. Natl. Acad. Sci. 84: 8355-8359.

Lee, W., P. Mitchell, and R. Tjian. 1987. Purified transcription factor AP-1 interacts with TPA-inducible enhancer elements. Cell 49: 741-752.

Leff, T., J. Corden, R. Elkaim, and P. Sassone-Corsi. 1985. Transcriptional analysis of the adenovirus-5 EIII promoter: Absence of sequence specificity for stimulation by ElA gene products. Nucleic Acids Res. 13: 1209-1221.

Lewis, E.J., C.A. Harrington, D.M. Chikaraishi. 1987. Transcriptional regulation of the tyrosine hydroxylase gene by glucocorticoid and cyclic AMP. Proc. Natl. Acad. Sci. 84: 3550-3554.

Lin, Y.-S. and M.R. Green. 1988. Interaction of a common cellular transcription factor, ATF, with regulatory elements in both Ela and cyclic AMP-inducible promoters. Proc. Natl. Acad. Sci. 85: 3396-3400.

Logan, J., S. Pilder, and T. Shenk. 1984. Functional analysis of adenovinus type 5 early region 1B. Cancer Cells 2: 527-532.

Melton, D.A., P.A. Krieg, M.R. Rebagliati, T. Maniatis, K. Zinn, and M.R. Green. 1984. Efficient in vitro synthesis of biologically active RNA and RNA hybridization probes form plasmids containing a bacteriophage SP6 promoter. Nucleic Acids Res. 12: 7035-7056.

Montminy, M.R. and L.M. Bilezikjian. 1987. Binding of a nuclear protein to the cyclic-AMP response element of the somatostatin gene. Nature 328: 175-178.

Montminy, M.R., K.A. Sevarino, J.A. Wagner, G. Mandel, and R.H. Goodman. 1986. Identification of a cyclic-AMP-responsive element within the rat somatostatin gene. Proc. Natl. Acad. Sci. 83: 6682-6686.

Murthy, S.C.S., G.P. Bhat, and B. Thimmappaya. 1985. Adenovirus EIIA early promoter: Transcriptional control elements and induction by the viral pre-early ElA gene, which appears to be sequence independent. Proc. Natl. Acad. Sci. 82: $2230-2234$.

Nevins, J.R. 1981. Mechanism of activation of early viral transcription by the adenovirus ElA gene product. Cell 26: 213220.

Nevins, J.R., H.S. Ginsberg, J.-M. Blanchard, M.C. Wilson, and J.E. Darnell, Jr. 1979. Regulation of the primary expression of the early adenovirus transcription units. J. Virol. 32: 727733.

Parks, C.L., S. Baneriee, and D.J. Spector. 1988. Organization of the transcriptional control region of the E1B gene of adenovirus type 5. I. Virol. 62: 54-67.

Piette, J., S.-I. Hirai, and M. Yaniv. 1988. Constitutive synthesis of activator protein 1 transcription factor after viral transformation of mouse fibroblasts. Proc. Natl. Acad. Sci. 85: 3401-3405.

Rice, S. and D.F. Klessig. 1985. Isolation and analysis of adenovirus type 5 mutants containing deletions in the gene encoding the DNA-binding protein. $J$. Virol. 56: 767-778.

Short, J.M., A. Wynshaw-Boris, H.P. Short, and R.W. Hanson. 1986. Characterization of the phosphoenolpyruvate carboxykinase (GTP) promoter regulatory region. J. Biol. Chem. 261: $9721-9726$.

Silver, B.J., J.A. Bokar, J.B. Virgin, E.A. Vallen, A. Milsted, and J.H. Nilson. 1987. Cyclic AMP regulation of the human glycoprotein hormone $\alpha$-subunit gene is mediated by an 18 base-pair element. Proc. Natl. Acad. Sci. 84: 2198-2202.

Stein, R.W. and E.B. Ziff. 1987. Repression of insulin gene expression by adenovirus type 5 ElA proteins. Mol. Cell. Biol. 7: $1164-1170$. 
Engel et al.

Thimmappaya, B., C. Weinberger, R.J. Schneider, and T. Shenk. 1982. Adenovirus VAI RNA is required for efficient translation of viral mRNAs at late times after infection. Cell 31: $543-551$.

Velcich, A. and E.B. Ziff. 1985. Adenovirus E1A proteins repress transcription from the SV40 early promoter. Cell 40: 705716.

Wu, L., D.S.E. Rosser, M.C. Schmidt, and A.J. Berk. 1987. A TATA box implicated in E1A transcriptional activation of a simple adenovirus 2 promoter. Nature 326: 512-515.

Yoshinaga, S., N. Dean, M. Han, and A.J. Berk. 1986. Adenovirus stimulation of transcription by RNA polymerase III: Evidence for an E1A-dependent increase in transcription factor IIIC concentration. EMBO I. 5: 343-354.

Zajchowski, D.A., H. Boeuf, and C. Kedinger. 1985. The adenovirus-2 early EIIA transcription unit possesses two overlapping promoters with different sequence requirements for E1A dependent stimulation. EMBO f. 4: 1293-1300. 


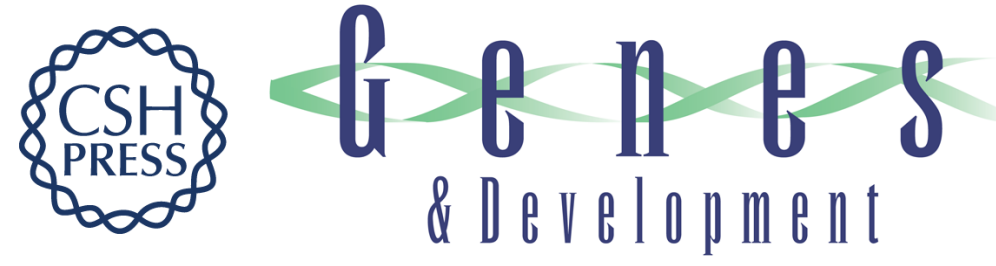

\section{cAMP acts in synergy with E1A protein to activate transcription of the adenovirus early genes E4 and E1A.}

D A Engel, S Hardy and T Shenk

Genes Dev. 1988, 2:

Access the most recent version at doi:10.1101/gad.2.12a.1517

References This article cites 57 articles, 26 of which can be accessed free at:

http://genesdev.cshlp.org/content/2/12a/1517.full.html\#ref-list-1

License

Email Alerting

Service

Receive free email alerts when new articles cite this article - sign up in the box at the top right corner of the article or click here.

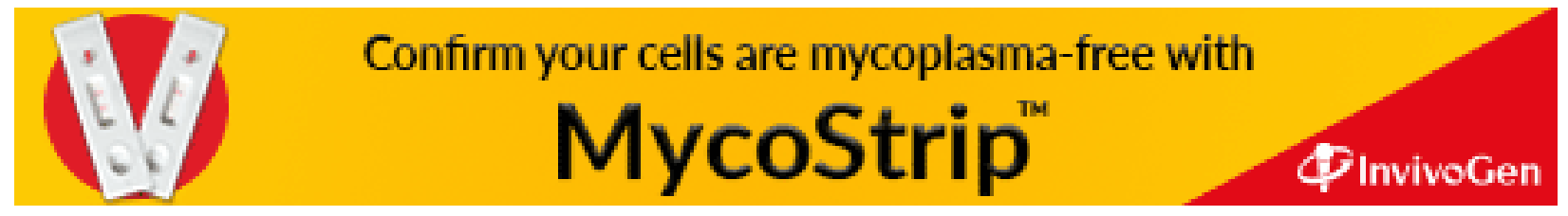

